DOI 10.18551/rjoas.2019-06.10

\title{
CITY BRANDING POLICY AND REGIONAL MARKETING IN INDONESIA
}

\author{
Nawangsari Ertien Rining, Suksmawati Herlina* \\ Faculty of Social and Political Sciences, University of Pembangunan Nasional "Veteran" \\ Jawa Timur, Surabaya, Indonesia \\ *E-mail : ertien.riningnawangsari@yahoo.com
}

\begin{abstract}
City branding is a form of communication that is built through a public policy that is used to market a city to form a perception of a city carried out by the relevant government. The implementation of city branding has been carried out by various countries including various regions in Indonesia. Especially with the existence of regional autonomy since 2000, each city competed to show its superiority. Various studies have been conducted to see the success of City Branding which can be measured through several related theories, such as Hexagon theory of Anholt's City branding. The purpose of this paper is to see the process of implementing city branding in Indonesia. The method used uses a qualitative approach with data sources derived from literature studies. It can be concluded that city branding policies have an impact on increasing income through the tourism sector which benefits the economy and prosperity of its people. While the problems that are often faced include the lack of participation resulting from a lack of government and community knowledge regarding the meaning, purpose, and benefits of city branding.
\end{abstract}

\section{KEY WORDS}

City branding, public policy, regional marketing, regional development.

City branding is a strategic concept for marketing a city, region, and country. Anholt in Luthfi (2013) revealed that city branding is an idea of how to apply an identity that is usually used for a product, into a place branding that stakeholders want to be of more value than the viewpoint of a consumer. The success of the city branding strategy is closely related to the influence of Place marketing concepts that shape the identity of a place and also with the support of the community and stakeholders/government. As a public policy, Intiah and Kriswibowo (2018) argue that the determinant of the success of the public policy is in the implementation steps in the field, or in other words, good implementation will produce good policy performance, as well as in the context of city branding policy in Indonesia. From the point of view of public sector marketing, Wibawanto (2015) argues that the place marketing approach greatly influences the concept of marketing in a place. Place branding is also needed to identify suitable brands according to the target conditions of the place and community group.

Although the purpose of city branding has been formulated, as in Cai's opinion in Qu, Kim, \& Im (2011), that is to build a positive image of a place and to distinguish the place from its competitors, there are many other thoughts in the formulation of city branding policies in Indonesia. The hope, through a branding approach in a city, can popularize a brand from a product owned by the city. The product here is everything that becomes the identity of a city. Please note that the implementation of city branding has been carried out by various countries including various regions in Indonesia. Moreover, with the existence of regional autonomy since 2000 , each Regency/city competes to show its superiority. Every region of the City / Regency in Indonesia has now used the city branding strategy to improve the existence of the region, they are also trying to attract the attention of local/foreign tourists and investors. In order to further review the success of the city branding strategy in a City / Regency area or in a country, further analysis is needed using the literature review method. This paper will look at how the concept of city branding has evolved in various regions and to assess the achievements of the implementation of city branding in Indonesia in recent years. 
As a form of policy in the public sector, of course, this study of city branding is interesting to be explored further.

\section{METHODS OF RESEARCH}

This study uses a qualitative approach using data in the form of literature in the form of books, proceedings, and scientific journals. Through the literature study approach, views, concepts, and comparisons of the implementation of public city branding policies will be obtained in Indonesia.

\section{RESULTS AND DISCUSSION}

According to Mathieson (2005: 22) in Intyaswono, Yulianto, \& Mawardi, (2016), brands are interpreted as something that can run the whole process of mixed communication of attributes, in the form of a logo or symbol that reflects a promise or emotional process between consumers and companies and create valuable influence for stakeholders and consumers. While another opinion states that Branding in the sense of city branding is to give a brand to the city so that it can be easily recognized and can form a city image to market the area both locally and internationally (Bawanti, 2016). So from the opinion of the experts, it can be concluded that branding is an effort to give and market a brand that can be a logo or symbol and other communication processes that can form a positive image/image to influence and attract consumers.

Wahyurini (2009) sees from the other side that city logo is closely related to the city branding communication framework which can increase international recognition of a city. City logo as a brand of city identity symbolizes city identity, a positive image of the city and a city branding strategy. Like in New York which has the I $\vee$ NY logo that can arouse tourist attraction and increase the love of the local community in their pride of living in the city. So that many of the companies and communities make the City Logo the design of their products which are then hunted by tourists as souvenirs. Melbourne has also spent more than AU\$250,000 only for design costs, city logo describes Melbourne as a sophisticated world city with a variety of components and features, which easily communicates with stakeholders, society, residents and even political culture.

On the other hand, there are some optimizations in the implementation of City Branding, such as the findings of Bawanti (2016) who conducted research in Jayapura Regency regarding city branding where the business carried out by the government was not optimal. This is because City branding has not yet formed an immigration and city logo city related to its natural beauty, especially in the beauty of Sentani lake which is often a tourist destination, as well as lack of accessibility and transportation that cannot support tourists to enjoy their visit. Then it is necessary to establish a city branding that must be able to show an attractive brand for visiting tourists. Such as the formation of a brand and a symbol to launch a good city branding can reflect the beauty of Sentani Lake and the cultural diversity of other local communities.

According to Sevin (2014) in Hambalah (2017), city branding is a collection of associations that are in someone's mind about a city or that are perceived by the city, which are the results of communication, values, and actions made by stakeholders the city. Whereas according to Kavaratzis (2004) in Jannah, Arifin, \& Kusumawati (2014) states that seeing city branding in the context of communication from the image of a city through three stages of communication namely primary, secondary, and tertiary. So it can be concluded that city branding is a communication context that is used to market a city to form a perception of a city carried out by the government concerned.

City branding can also appear automatically without a planned strategy from the local government because city branding can be interpreted as a society's perception of social or historical environmental conditions that exist in a city or country. This is in line with that expressed by Koob \& Samuel, (2010) regarding Place Branding and Destination Marketing in Paris which shows the results that city branding is obtained from its image that is 
internationally known as it is called "city of love", "city of light" and "City of fashion". Branding is formed by people and tourists themselves who consider the conditions of the social environment and the charm of the place/city buildings in Paris, and the government only strives to promote tourism through the development of website-based communication and information technology to lead public opinion which is then formed.

According to Anholt (2007: 108) in Intyaswono et al. (2016), there are six aspects to measuring city branding effectiveness, namely: 1. Presence: based on the international status of the city and knowledge of the city globally. This is also used as a benchmark for the contribution of cities in science, culture, and governance globally. 2. Potential: measuring how economic and educational opportunities in a city. For example, opportunities to find employment, or opportunities to get a higher education. 3. Place: measuring people's perceptions of the physical aspects of each city in terms of climate, environmental cleanliness and how the city spatial layout. 4. Pulse: measures the perception that there are interesting things in a city, whether it's an activity or an event that is able to fill leisure time or can attract visitors. 5. People: measure how friendly local people are, what communities are in the community and how the area is able to provide a sense of security for visitors. 6 . Prerequisite: determine how people see the quality in a city, whether the city is satisfactory, have standards for public facilities such as schools, hospitals, transportation, and sports facilities.

In order to know the effectiveness and efficiency in the success of the city branding strategy, a measurement effort is needed. There are several measurement models that can be done to measure the success of city branding. Moreover, in various regions in Indonesia emphasize city branding in the marketing of a city/district in an effort to improve the tourism sector. As a study conducted by Hilman \& Megantari, (2018) related to city branding as a strengthening of local tourism in East Java Province which obtained results that the city branding strategy is very effective in increasing tourist visits. This is because city branding has been able to provide excellent references for tourists in an effort to increase tourist visits in various areas of East Java, and considering tourism is one sector that provides a lot of income for East Java Province, it can be concluded that city branding can increase PAD / Regional Revenue through the tourism sector.

The other research conducted by Wahid (2018) shows the success of the application of city branding in Lumajang in 2016 which has a considerable impact on the increasing number of tourist visits. With the city branding, "I Like Lumajang" can make tourism and culture services become the highest 3 major contributions in increasing the PAD/Regional Revenue of Lumajang in 2014-2017. The marketing strategy carried out by the Government of Lumajang Regency was seen from three elements of city branding: brand personality, brand positioning, and brand identity. Brand personality is the character chosen as the best way to communicate the brand to the target user, while the brand positioning shows how a brand can be known and placed in the minds of consumers, and brand identity can be interpreted as a set of words, impressions, and a set of customers perception of the brand.

In Brand Personality, Lumajang Regency uses the tagline "i like Lumajang" does not have a strong attachment but is able to foster a sense of love for Lumajang Regency with its various potentials, and in Brand Positioning, Lumajang Regency only focuses on communicating its city branding to the local community. foreign tourists, so that tourist visitors there are emotionally involved visiting as a form of pride in their hometown or having relatives living in Lumajang. Whereas in Brand Identity focused on aspects of visualization with logos/symbols and other marketing media it has been considered able to attract the attention of tourists.

According to Yuli (2011) in Indonesia, there is no legal protection for city branding brands. As well as not focusing on brand positioning and brand identity, this certainly affects the regions that have a particular product brand. As a company, Indonesia is a corporate brand that houses 33 provinces as a product brand. Without a clear national positioning, it greatly influences marketing activities, especially in terms of communication. Not surprisingly, then some regions took their own initiative to do branding even though some of them often did not show the uniqueness of the area. 
Besides that effective city branding measurements can also be carried out using The Hexagon Brand Theory theory put forward by Anholt in the previous section, revealing that there are six dimensions in city branding strategies which include the presence, potential, place, pulse, people, and prerequisite. This is reinforced by the research conducted by Lutfi and Widyaningrat (2013) which can be concluded that the city branding concept with reference to The City Hexagon Brand created by Simon Anholt is the right strategy so that the city has an identity and is better known by the wider community. However, the application of the city branding concept must be considered because it is related to several important parties in forming the identity of a city. City branding is not only the duty of the government, but also business people, local residents, community leaders, and migrants are interrelated to create a positive image of the city. This will attract domestic and foreign tourists to visit so that it will not form a negative pattern of visiting behavior, and attract investors to come and develop the city's potential.

Chaerani (2011) also conducted an analysis of the implementation of city branding in Surakarta City using Anholt's theory, and the results of the study showed that Surakarta City had a potential aspect as indicated by its strategic location in the middle of Java island and aspects of people can be assessed from hospitality of people to the most prominent tourists, but the City of Solo is weak in the place dimension. Another advantage is the pulse aspect because Solo has many interesting artistic and cultural activities. Then it can be concluded that the Anholt theory can reach all aspects in the area so as to obtain the accuracy and effectiveness of measurement of city branding strategies. On the other hand, Christin \& Fauzan (2015) conducted research conceived by focusing on Prerequisites influence on city branding. Bandung as a world tourist city established by UNESCO on the 25th September 2013 in Beijing, must have adequate facilities to support easy access for tourists, such as the aspect of a city tour with Bus Bandros. This research shows that Prerequisite is very influential in facilitating access to tourism development which is a city branding destination.

There are also several other studies that use the city branding strategy measurement model from Merrilees (2012) in Purwianti \& Lukito (2014) where there are six dimensions consisting of nature, business opportunities, transportation, social bonding, cultural activities. Like research conducted by Kawi \& Maulana (2017) in looking at the City Influence of Balikpapan City branding on Brand Attitude. This research is motivated by the city of Balikpapan which has great potential for oil and gas but wants to change its image to become a tourism city. Balikpapan city held a voting or city branding name selection through the official website of the Balikpapan government, www.Balikpapan.go.id by making 11 new name categories proposed by several stakeholders. The results showed that the effect of city branding on the brand attitude based on the simultaneous determination test showed only $31.9 \%$ of city branding influence on brand attitude. Whereas, $68.1 \%$ is influenced by variables not examined. Business opportunity variable becomes the variable that most influences the brand attitude. Because the majority of the people of Balikpapan City are immigrants, the website of the Balikpapan City government was reported. Besides research Purwianti \& Lukito, (2014) using the same method and showing the results that the factors that influence the brand city of Batam City as a place of residence for residents of the city of Batam are factors of business opportunity, social bonding, and networking.

In addition, several studies have tried to reveal whether there is a connection between city branding, city image and the decision of tourists to visit. As conducted by Indriano \& Kuswoyo (2017) in his research which resulted in an analysis of the relationship between city branding and city images and the visiting decision of tourists. The results obtained are that city branding has a significant effect on city image and the decision to visit tourists so that all three of them influence each other. So if Purwakarta wants to increase the PAD / Regional Revenue through the tourism sector then it must be able to increase interest in visiting tourism decisions by also increasing the city image so that tourists know well the attractive tourist conditions in Purwakarta. In line with the research conducted by Wandari, Kumadji, \& Kusumawati, (2014) the results show that these three aspects influence the city branding "Shining Batu". With city branding results having a significant effect on city image, city branding also has a significant effect on visiting decisions and city image has an influential 
but not significant effect on tourist visiting decisions. The research conducted by Intyaswono et al. (2016) also shows the success of the city branding "Shining Batu" which can describe the three leading sectors (agriculture, tourism, and education) that attract foreign tourists so they can increase the Regional Revenue.

Another study conducted by Jannah et al. (2014) also analyzed the influence of city branding and city image on the decision to visit tourists to Banyuwangi. This study shows that 1) the city branding variable "The Sunrise of Java" has an influence on the Banyuwangi city image, especially in terms of tourism potential, and local residents who are able to create a comfortable atmosphere for tourists. 2) the city branding variable has a significant effect on visiting decisions but only shows a small percentage, this is due to the maximization of Banyuwangi branding. The Banyuwangi Regency Government is currently still an effort to improve the branding promotion of "The Sunrise of Java" by making it a cover in Gatra magazine, and making Discover Banyuwangi videos and disseminated via YouTube and DVDs aimed at non-local tourism Banyuwangi while the respondents in this study are local residents of Banyuwangi. 3) that city image has an effect but not significant to visiting decisions, This is because most of the respondents came from Banyuwangi so that for them the Banyuwangi city image was not used as a consideration to visit Banyuwangi tourism.

Many of the various countries and regions of the city are carrying out city branding in order to get the attention of local and foreign tourists in an effort to increase their income from as dirty as tourism and hope to be able to attract investors. Various methods were used to emphasize tourism, some using socio-cultural aspects of society and history. As the research conducted by Pecot (2015) discusses city brand management that focuses on the role of Heritage Brands in City branding communication, showing the results that local residents are very concerned about various elements of city branding formation through the City Brand Heritage $(\mathrm{CBH})$ which favoring the social and historical cultural heritage that develops in the community, but other results are shown by tourists who pay less attention to the value of the cultural heritage and focus more on clearer elements such as the dimensions of places known as tourist destinations. Therefore, if the government will carry out $\mathrm{CBH}$, it needs to pay full attention to the chosen promotion/marketing methods to provide easy access that can attract tourists.

Learn from Dinnie's (2009) research in South Korea which is trying to do city branding through the promotion of various cultures and foods and the development of sophisticated technology through the distribution of volunteers who work in information technology companies, the education sector and the environment around the world. This study looks at the challenges of the entry of the business sector that can influence the formation of city images, such as the response of some people when asked about South Korea called Samsung brands and K-Pop idols. The same challenge must be experienced by Singapore. It was proven by research conducted by Yee, (2009) about national branding in Singapore which turned out to continue to update its brand tagline starting from the last, Uniquely Singapore (2004), New Asia (1996), Surprising Singapore (1985), Instant Asia (1970), The Garden city (1967) and The Lion city as the first branding since the establishment of this country. This is done by Singapore to build a brand that can withstand the challenges of business and economic development in this country. Young, (2012) looked at city branding and urban tourism in Seoul and Taipei and obtained results that both chose to form a positive image of city branding through the creativity of art and local culture, with its Seoul megaproject (Design Seoul planning) and Taipei ( Taipei Beautiful planning).

Murfianti, (2010) conducted research in Indonesia precisely in the city of Solo that uses city branding in the formation of the city's identity. The city of Solo chose to elevate the social and cultural life of the people through the archipelago batik tradition. Then Larasati \& Nazaruddin, (2018) conducted research on Tourism Potential in the Formation of City Branding in Pekanbaru City. The results showed that the city branding carried out had not been able to show the potential of cultural arts, culinary, natural tourism and historical tourism. So from these results it is necessary to review the vision and strategy in city branding as the gateway to Malay culture, there need to be synergies between stakeholders (such as local residents, employers, and government), improving tourism infrastructure, 
forming public spaces (such as parks), and the need for communication through a tagline that is in accordance with the branding of the city of Pekanbaru in various districts of the region.

The city branding to improve the tourism sector can also be done through political and economic stability, a quality education system, and the development of high-tech systems and also their natural beauty. Like research revealed by Paschou \& Metaxas, (2013) about city branding in Stockholm, with the title "Capital of Scandinavia" which means rulers on the Scandinavian peninsula (northern Europe). This is pinned because Stockholm succeeded in making the city a safe, comfortable and friendly city for immigrants and investors by strengthening political and economic stability in the country. In addition, the improvement of the tourism sector in city branding communication can also take advantage of the potential of its natural resources, such as the research conducted by Hambalah (2017) which in the formation of the city of Surabaya as a maritime city based on its marine potential. Shown by the port of Tanjung Perak, it also functions as a human transportation port, also has NorthQuay as a port for overseas cruise ships who want to transit to Surabaya, Sentra Pasar Ikan Bulak (Center of Fish Market) which stands majestically on the edge of Kenjeran Beach, there is a Suramadu bridge as a liaison between cities, The existence of the Pangkalan TNIAL V (Navy Fleet Base) in the city of Surabaya which is also the largest Naval Fleet Base in Indonesia provides many opportunities for the city of Surabaya to host the TNI-AL (Navy) events. Coupled with the tourist attraction, the unique Jalesveva Jayamahe Statue Monument and the only one found in Indonesia.

City branding can also be used as a development of the tourism sector that targets the business market. Febrianur (2016) saw the impact of Enjoy Jakarta and YourSingapore city branding on the development of Meeting, Incentive, Convention and Exhibition (MICE), where MICE itself is a segment in tourism that targets the business market for business people where they can hold meetings (meetings), traveling (as part of incentives or gifts to business people), conducting conferences and exhibitions. Bringing YourSingapore can make someone no longer feel alienated in Singapore even though it is the first time they come to Singapore, this brand that builds closeness with tourists shows a target interest in the MICE market which certainly prioritizes quality over quantity, and causes Singapore to be chosen as the number one city meeting International Congress and Convention Association (ICCA) in the Asia Pacific region. It is inversely proportional to the results of research in Jakarta with the Enjoy Jakarta brand, where although this branding still exists today, there is no synergy between stakeholders and the public and business actors.

Challenges and Problems in the implementation of City Branding in Indonesia. The implementation of City Branding has been carried out in various regions, but many of them are still not optimal because they have not been able to show their various potentials. We need to know that the main thing that is a challenge in implementing city branding and needs to be considered is the process of building city branding itself, as stated by Lestari, (2016) that the process of building City Branding begins with exploring city identity that comes from regional potential and uniqueness which are owned.

Besides that, the challenge that must be faced by Indonesia in carrying out city branding to increase income from the tourism sector is having to be able to provide transportation, accommodation and public facilities that are good at supporting tourism potential. Like the research conducted by Christin \& Fauzan (2015) in Bandung, which was motivated by the characteristics related to the establishment of world tourism cities, one of the must-have values is having adequate facilities to support easy access for tourists, such as the city tour aspect. Then in line with the research carried out by Bawanti, (2016) in Jayapura, the biggest challenge from the results of the research was that transportation and tourism access received low ratings compared to several other elements of the quality of tourism products.

While the problems that are often faced include the lack of participation resulting from a lack of government and community knowledge regarding the meaning, purpose and benefits of city branding. This is in line with the findings of Romandhona, (2016) in Surabaya which shows the results that the level of knowledge and understanding of the community regarding 
the existence of "Sparkling Surabaya" city branding can be said to be lacking. Government officials also do not really understand the meaning of the implementation of "Sparkling Surabaya", the concern of the private sector is still limited to profit alone, and there are still many apathetic attitudes from the young generation towards the direction of tourism development in the city. Then the communication of city branding also needs to be considered by the regional government to be right on target with the expected goals. City Branding Communication must pay attention to global competition and the development of information technology in promoting branding.

\section{CONCLUSION}

Most of the research conducted shows the results that city branding strongly supports the formation of the image/identity of a country or a city, and is considered quite effective in marketing various products it has. The purpose of this city branding is to increase revenue through the tourism sector. The benefits are increasing the economy and prosperity for the people. The communication of city branding in the development of the tourism sector can be done through various ways, such as the creation of taglines, symbols or social empowerment of society and culture, through the exploitation of natural, culinary, and economic-political stability and global competition in the business market. Then measuring the success of city branding can be done using several theories, including The Hexagon Brand Theory theory put forward by Anholt and the theory expressed by Merrilees which consists of nature, business opportunities, transportation, social bonding, cultural activities. In addition, several studies also try to reveal whether there is a connection between city branding, city image and the decision of tourists to visit.

\section{ACKNOWLEDGMENTS}

The authors would like to thank the LPPM UPN "Veteran" Jawa Timur for supporting funding through the Riset Unggulan Keilmuan scheme.

\section{REFERENCES}

1. Bawanti, A. (2016). Analisis City Branding Dalam Pembangunan Destinasi Pariwisata Kabupaten Jayapura. Jurnal Media Wisata, 14(1), 365-381.

2. Chaerani, R. Y. (2011). Pengaruh City Branding Terhadap City Image (Studi Pencitraan Kota Solo: "The Spirit of Java). JRK, 2(4).

3. Christin, M., \& Fauzan, S. F. (2015). City Branding Kota Bandung melalui Bus Bandros. Jurnal Komunikator, 7(2).

4. Dinnie, K. (2009). Repositioning the Korea Brand to a Global Audience: Challenges , Pitfalls , and Current Strategy, 4(9).

5. Febrianur, Z. (2016). Dampak City Branding Eenjoy Jakarta \& YourSingapore Terhadap Perkembangan MICE. Journal IImu Hubungan Internasional, 4(4).

6. Hambalah, F. (2017). Surabaya Sebagai Kota Maritim: Strategi Pemasaran. Jurnal Aplikasi Administrasi, 20(1), 61-69.

7. Hilman, Y. A., \& Megantari, K. (2018). Model City Branding Sebagai Strategi Penguatan Pariwisata Lokal Provinsi Jawa Timur. Jurnal Komunikasi Dan Kajian Media, 2(2), 22-35.

8. Indriano, J., \& Kuswoyo, C. (2017). Pengaruh City Branding Pada City Image dan Keputusan Berkunjung Wisatawan ke Kabupaten Purwakarta. Jurnal Manajemen Maranatha, 17(1), 41-52.

9. Intiah, I., \& Kriswibowo, A. (2018). Kinerja Implementasi Penuntasan Buta Aksara Di Kecamatan Karangjambu Kabupaten Purbalingga. Jurnal Dinamika Governance, 8(2).

10. Intyaswono, S., Yulianto, E., \& Mawardi, M. K. (2016). Peran Strategi City Branding Kota Batu Dalam Trend Peningkatan Kunjungan Wisata Macanegara ( Studi Pada Dinas Pariwisata dan Kebudayaan Kota Batu ). Jurnal Administrasi Bisnis, 30(1), 65-73.

11. Jannah, B., Arifin, Z., \& Kusumawati, A. (2014). Pengaruh City Branding dan City Image 
Terhadap Keputusan Berkunjung Wisatawan ke Banyuwangi. Jurnal Administrasi Bisnis, $17(1), 1-7$.

12. Koob, J., \& Samuel, O. (2010). Place Branding and Destination Marketing Case: Marketing of Paris. Tourism Destination Developement, Dalarna University.

13. Larasati, D., \& Nazaruddin, M. (2018). Potensi Wisata dalam Pembentukan City Branding Kota Pekanbaru. Jurnal Komunikasi, 2016. https://doi.org/10.20885/komunikasi.vol10.iss2.art1

14. Lestari, R. B. (2016). Membangun Citra Sebuah Kota Dalam Persaingan Global Melalui City Branding. Jurnal Forum Bisnis Dan Kewirausahaan, 5(2).

15. Murfianti, F. (2010). Membangun City Branding Melalui Solo Batik Carnival. Jurnal Penelitian Seni Budaya, 2(1).

16. Paschou, E., \& Metaxas, T. (2013). City Branding Of Stockholm. In MPRA Paper. Munich Germany: University Library of Munich. Retrieved from https://mpra.ub.unimuenchen.de/48118/1/MPRA_paper_48118.pdf

17. Purwianti, L., \& Lukito, Y. R. D. (2014). Analisis Pengaruh City Branding Kota Batam Terhadap BrandAttitude. Jurnal Manajamen, 14(1), 61-80.

18. Qu, H., Kim, L. H., \& Im, H. H. (2011). A model of destination branding: Integrating the concepts of the branding and destination image. Tourism Management, 32, 465-476. https://doi.org/10.1016/j.tourman.2010.03.014

19. Wahid, W. N. (2018). Strategi Pemasaran Pariwisata Melalui City Branding Dalam Meningkatkan Pendapatan Asli Daerah ( PAD ) Kabupaten Lumajang. Jurnal Kebijakan Dan Manajemen Publik, 6(2), 1-7.

20. Wandari, L. A., Kumadji, S., \& Kusumawati, A. (2014). Pengaruh City Branding "Shining Batu" Terhadap City Image dan Keputusan Berkunjung Wisatawan ke Kota Batu Tahun 2014. Jurnal Administrasi Bisnis, 16(1).

21. Wibawanto, S. (2015). Pendekatan Konseptual PlaceMarketing dan Place Branding dalam Destination Branding. Jurnal Fokus Bisnis, 14(2).

22. Yee, F. W. (2009). Nation branding: A case study of Singapore. UNLV Theses, Dissertations, Professional Papers, and Capstones.

23. Young, Y. E. (2012). City Branding and Urban Tourism: A Case Study of Seoul and Taipei. In In 6th Conference of the International Forum on Urbanism (IFoU): TOURBANISM, Barcelona (pp. 1-10).

24. Yuli, A. (2011). City Branding Sebagai Strategi Pengembangan Pariwisata Ditinjau Dari Aspek Hukum Merek (Studi Kasus City Branding Daerah Istimewa Yogyakarta Sebagai Daerah Tujuan Wisata Unggulan di Indonesia). Jurnal IImiah IImu Hukum QISTI, 5(1).

25. Romandhona, D. (2016). Pengelolaan Partisipasi , Potensi , dan City Branding Sebagai Upaya Pengembangan Industri Pariwisata Di Kota Surabaya. Universitas Airlangga.

26. Kawi, T. G., \& Maulana, S. (2017). Pengaruh City Branding Kota Balikpapan Terhadap Brand Attitude. E-Proceeding of Management, 4(2), 1978-1985.

27. Luthfi, A., \& Widyaningrat, A. I. (2013). Konsep City Branding Sebuah Pendekatan "The City Brand Hexagon" Pada Pembentukan Identitas Kota. Seminar Nasional Manajemen Dan Bisnis Ke-3, 315-323

28. Pecot, F., \& Barnier, V. (2015). City Brand Management: the role of Brand Heritage in City Branding. In 14th IMTC (International Marketing Trends Conference), Paris.

29. Wahyurini, O. D. W. (2009). The Significance of City Logo in City Branding Strategy City. In Recent Researches in Engineering Mechanics, Urban \& Naval Transportation and Tourism (pp. 79-84). Cambrigde: WSEAS Conferences. 